\title{
THE IMPROVEMENT OF ENGLISH WRITING AND STUDENTS' MOTIVATION THROUGH BRAINSTORMING
}

\author{
Varia Virdania Virdaus \\ Email: varia.virdania@gmail.com \\ Narotama University Surabaya
}

\begin{abstract}
Brainstorming activity is a main factor that can give effect on students' writing motivation. Teaching English writing by using brainstorming strategy is really important especially to increase students' motivation. This research is aimed at investigating the effect of brainstorming and its relation to students' motivation in English writing for the second semester students of Management Major of STIE Perbanas Surabaya, numbering 25 students in academic year 2018-2019. Classroom Action Research (CAR) method was applied in this research. Researcher could investigate and analyze brainstorming process by using this method. Applying brainstorming strategy, the participants (students) were more motivated in terms of writing, which at this time was English writing with a particular topic. Result of this study revealed that brainstorming strategy could improve students' English Writing skill and their motivation in writing. They could produce good and effective words, and also interesting answers. Based on the fact, brainstorming strategy is suggested for teaching English Writing. Students' motivation in writing much higher than without brainstorming strategy.
\end{abstract}

Key Words: Brainstorming, Motivation, English Writing

\begin{abstract}
ABSTRAK
Kegiatan brainstorming adalah faktor utama yang dapat memberikan efek pada motivasi menulis siswa. Mengajar menulis bahasa Inggris dengan menggunakan strategi curah pendapat sangat penting terutama untuk meningkatkan motivasi siswa. Penelitian ini bertujuan untuk menyelidiki pengaruh brainstorming dan hubungannya dengan motivasi siswa dalam menulis bahasa Inggris untuk mahasiswa semester kedua Jurusan Manajemen STIE Perbanas Surabaya, yang berjumlah 25 siswa pada tahun akademik 2018-2019. Metode Penelitian Tindakan Kelas (PTK) diterapkan dalam penelitian ini. Peneliti dapat menyelidiki dan menganalisis proses brainstorming dengan menggunakan metode ini. Menerapkan strategi curah pendapat, para peserta (siswa) lebih termotivasi dalam hal penulisan, yang saat ini adalah penulisan bahasa Inggris dengan topik tertentu. Hasil penelitian ini mengungkapkan bahwa strategi brainstorming dapat meningkatkan keterampilan menulis bahasa Inggris siswa dan motivasi mereka dalam menulis. Mereka dapat menghasilkan katakata yang baik dan efektif, dan juga jawaban yang menarik. Berdasarkan fakta, strategi curah pendapat disarankan untuk mengajar Menulis Bahasa Inggris. Motivasi siswa dalam menulis jauh lebih tinggi daripada tanpa strategi curah pendapat.
\end{abstract}

Kata Kunci: Brainstorming, Motivasi, Penulisan Bahasa Inggris 


\section{INTRODUCTION}

Writing is very important in our life. By writing we are able to share our ideas and thoughts. Besides listening and speaking, writing also has an important role in effective communication. Nowadays, communication is more often done in writing than orally, as we find in social media. In learning English, writing is one step to speak English more organized and easy. However, learning to write in English is still not easy, especially for non-English Department students.

Writing also requires motivation, if students are motivated to write then the writing that they produce will be better and full of good ideas, and of course the content of their writing more interesting. Based on Lathif, Masyhudi (2017), motivation becomes one of the determinants of one's success in second and foreign language learning. Motivation is an area in which teachers can play a role in influencing and giving positive feedback to students from time to time.

Students who have high learning motivation, especially in learning English, then their achievement in learning English will also be good. Conversely, if less motivation in learning English, then student achievement will also decrease. Student learning motivation often occurs up and down, one of them because of their boring learning methods. Brainstorming has now become one way to improve students' learning motivation to be more creative and not boring. Brainstorming activity is a main factor that can give effect on students' writing motivation. Brainstorming and writing motivation are two main things in second language learning.

In fact, teaching English writing by using brainstorming method is really important especially to increase students' motivation. But somehow, teachers or lecturers use different method in giving brainstorming to students without examining how it could influence the students' motivation in writing. The same thing is also revealed by Mohammad, Mohammad and Ali Ahmed (2013), that EFL teacher for English usually uses different method for brainstorming. Literally, the use of brainstorming helps the student to think creatively, discuss, and solve the problems.

A good method can give powerful effect in motivating students to start writing English. Problems that they usually faced in writing English are varied, as they lack of vocabularies, find some difficulties in building sentences, or perhaps lack of ideas about what 
to write. By using Brainstorming, it is hoped that students' motivation in writing English could increase.

Based on the background above, researcher formulates the research problems as follows: 1) How can brainstorming give effects to students' motivation in writing English? 2) How is the process of implementation of brainstorming that can motivate students in writing English? According to the statement of the problems, the researcher is aimed to find out: 1) Describing how brainstorming give effects to students' motivation in writing English, 2) Describing the process of implementation of brainstorming that can motivate students in writing English. This research is aimed at investigating the effect of brainstorming and its relation to students' motivation in English writing for the second semester students of Management Major of STIE Perbanas Surabaya, numbering 25 students in academic year 2018-2019.

\section{LITERATURE REVIEW}

\section{Writing}

Writing has been with us for several hundred years, and it is very important for our lives. Millions of people rely on writing although not everyone can read and write. Writing becomes one of the important factors of communication in society. Based on Coulmas, writing has six meaning that can be distinguished as follows: (1) A system of recording language; (2) The activity of putting such a system to use; (3) The result of such activity, a text; (4) The particular form of such a result, a script style such as block letter writing; (5) Artistic composition; (6) A professional occupation.

According to William Hazzlit, the nineteenth-century novelist, "The more a man writes, the more he can write." This quote means, students will not make much progress in writing if they are not given opportunities to write, develop, and explore their ability. Graham \& Perin (2007b) also stated that students should spend at least one hour or even more each day in the process of writing (planning, revising, authoring, or publishing text) in order to improve their skill. There are multiple purposes for students to learn to write: for communicating with others (by business letter, by note, etc); Learning content material; Informing others; Responding to literature; and demonstrating knowledge.

\section{Motivation}


Motivation is important encouragement of human behavior that guarantees higher performance in any field. Psychologist said that human motivation as being 'moved to do something' that satisfies the fundamental need for 'competence, autonomy and relatedness' (Ryan and Deci, 2000:54; 57). A 'moving idea or fact or judgment' might trigger personal interest and consequently intrinsic motivation (Walker 1952: 6) in Kirchhoff, Leonie (2016).

Motivation intention depends on family relationship with second language learners, personal experience, impact of the social environment, etc (Noels, 2001; Dornyei, 2005). In second and foreign Language learning, motivation becomes the primary factor in determining one's success. This is in accordance with Dornyei (1994), motivation has become one of the main factor in students' achievement in learning second and foreign language. Based on Oxford \& Shearin (1996), students who have no motivation in learning second and foreign language, they cannot develop their ability.

\section{Brainstorming}

Arivananthan (2015) stated that Brainstorming is meant to stimulate the brain into thinking about issues in a new way. It encourages people to arrest conventional, logical thinking and embrace spontaneity, originality, and imagination. Participants in a Brainstorming session express their thoughts or ideas quickly and spontaneously. The goal is to collect as many ideas as possible in a short time. So that the greater the number of ideas generated, the greater the chance of producing English essay and effective solution.

Based on Eikenberry (2007) statement, brainstorming strategy conduct seven spurring questions, as follows:

1. How would $X$ do it (or solve this problem)? In the place of "X" you can place another department, another company, your Mother, a 10 year old, Benjamin Franklin, a character from a book or movie, anybody.

2. What would we do if the problem were twice as big (or half as big)? Looking at extremes is another way to spur new ideas.

3. How would we solve the opposite problem? By reversing the problem and making that list, we are often able then to turn those answers back around into new alternatives.

4. What does this problem remind us of? If we can find other situations in our experience to connect to this situation, new ideas will come out. 
5. How is this problem like $X$ ? In this case the " $X "$ is any word or phrase. By forcing the connections to the random word, new ideas will burst forth. To get your word you can open a dictionary to a random page and find a random word or you can use a random word list that you have previously prepared.

6. How can we do A and B? Perhaps the best alternative isn't with one idea.

7. How can we combine some of the ideas we have to find new and different ideas?

These questions can be asked by Teachers/ Lecturer or Leader, to help Students spur their thoughts. Each of the questions will create a new perspective and generates new connections in their minds.

\section{METHODOLOGY}

This research used Classroom Action Research (CAR) as the design and applying a spiral model as suggested by Kemmis and Taggart (1988) consisting of planning, acting, observing, and reflecting. It was used because of some reasons: 1) This research was done in natural ways; 2) This research concerned to improve motivation in English writing.

The participants of this study were 25 Management Major Students of STIE Perbanas Surabaya, at the academic year 2018/2019. They were at the second semester when this study was conducted. The second semester students were chosen because they had English subject at this semester. The researcher could easily meet the students once a week, so that it was a good time for collecting data to conduct the research.

The procedure of collecting data was: 1) Quantitative data were taken from writing test given by the researcher during the process of teaching; 2) Qualitative data were taken by the researcher by writing the lecturer's and students' activities and creativities during the process of teaching and learning English. The participants completed all the process by giving ideas and answering the $\mathrm{W} \& \mathrm{H}$ questions through writing.

After the data have been collected, they were analyzed as the follow: for quantitative data, the researcher applied the mean formula for the assessment, for qualitative data the researcher collecting the raw data, reducing the raw data, and analyze the data. As stated in Mohammad and Ali (2013), the analysis of the result was based on lecturer's observation during the process of brainstorming and students' reflections on the process.

\section{RESULT AND DISCUSSION}

\section{Cycle 1}


This research investigated the improvement of English Writing and students' motivation through brainstorming from Management Major students of STIE Perbanas Surabaya in the second semester 2018/2019 numbering 25.

Brainstorming could motivate students to discuss, think creatively, solve the problem, and finish the task given individually or in a team. By brainstorming, students compiled some ideas and examples for a given topic and it also helped them to develop their topic. So that, they had motivation to learn and write in English.

Motivation could indicate how students learn effectively. When motivation is high, students could learn effectively, but when motivation is low, students could take longer time to study or to learn something especially the writing skill (Prakash, 2007). If brainstorming and motivation were collaborated together as tools for English writing learning, the result for students' skill and comprehension toward English writing must be good. It was expected to occur to the Management major students of STIE Perbanas Surabaya where they had motivation in writing English.

\section{a. Meeting 1}

The researcher is the main source of data, because she was not only as a researcher, but also as a lecturer. At the beginning of the class, the lecturer prepared the class for English subjects, included greeting and checking students' presence. Time allocation was $2 \times 45$ minutes (1 meeting). Students were given writing material, after that they wrote free topic paragraphs. The researcher identified the answers from the students. Most of them wrote paragraphs irregularly and out of topic.

\section{b. Meeting 2}

Lecturer (researcher) prepared the class for the English Subject. The lecturer gave the students writing test by giving them certain topic "Indonesian Economic Condition". This topic was very good to be given because it was appropriate with their major. First step, students wrote paragraphs about the topic given and then they submitted to the lecturer directly after finished. Next, the lecturer made sure that the students had focused on the materials (the topic), so that, she continued to give them brainstorming sheet.

Researcher (lecturer) applied one of brainstorming strategy that is used by Eikenberry (2007). Researcher used this strategy because it is easier to be applied and delivered to the students than other brainstorming strategies. There are seven questions (brainstorming sheet) to conduct this brainstorming strategy, as follows:

\section{How would "students" do it (or solve this problem)?}


"Students were asked about the solution of the problem based on the topic given"

2. What would we do if the problem were twice as big (or half as big)?

"Make students try to think another way to spur new ideas"

3. How would we solve the opposite problem?

"By reversing the problem and making that list, Students were often able then to turn those answers back around into new alternatives"

4. What does this problem remind us of?

"Students were asked to find other situations in their experience to connect to this situation, and then new ideas would come out"

5. How is this problem like $X$ ? (In this case the " $\mathrm{X}$ " is any word or phrase).

"By forcing the connections to the random word, new ideas will burst forth. To get the students' words they opened a dictionary to a random page and found a random word or they used a random word list that they have previously prepared."

6. How can we do A and B?

"Perhaps the best alternative isn't with one idea, Students had to think more than one thing"

7. How can we combine some of the ideas, we have to find new and different ideas?

"Students had to think how to combine some of their ideas to be good statements"

Each of the questions created a new perspective and generates new connections in their minds. Each student was given a sheet of brainstorming strategy (consist of 7 questions). This procedure was aimed to identify English Writing skill for students. The answer sheets were submitted to the lecturer, then the lecturer evaluated all the answers (step 1 and step 2) in meeting 2 and wrote the mark in writing rubric.

\section{Observing}

The researcher tried to identify the problem in cycle 1 . There were some problems during the writing learning process by using brainstorming strategy. In the beginning, students did not understand when teacher applied brainstorming strategy to their writing, because it was the first time for them using this strategy. After meeting 2, students began to understand the brainstorming strategy. Based on students' writing score, there were 9 students or $36 \%$ who got $<75 ; 5$ students or $20 \%$ who got score between $76-80 ; 11$ students or $44 \%$ who got score between 81-90; and no students got the score between 91-100. The result from cycle 1 was not satisfying because it was still out of the target. There were 9 students $(36 \%)$ who got low scores. 


\section{Reflection}

From the result of the observation, students seemed still confused with the brainstorming strategy. They did not know about the process and they did not understand how to build sentences using the brainstorming strategy. The result of writing test did not match the criteria of mastery learning that is $75 \%$ individually and $85 \%$ classically. Based on the scores of writing test, there were still many students got low scores i.e. 36\%. From the result in cycle 1 , the researcher conducted cycle 2 with some revisions on the strategy of applying brainstorming.

\section{Cycle 2}

\section{a. Meeting 1}

Lecturer prepared English Writing class as usual, after that Lecturer applied Effective Brainstorming strategy for the first meeting in cycle 2. First of all, she explained the rules of this strategy. Lecturer divided the class into 5 (five) groups consisting 5 (five) students each to conduct effective brainstorming. Lecturer defined the idea to be brainstormed then let the leader of each groups to control. In this meeting, every students of each groups was allowed to contribute. All ideas were evaluated until all ideas were gathered.

The brainstorming was started, the leader selected the member of the group to share their answer. In this situation, everyone did not need to evaluate or criticize the answers until the process of brainstorming was completed. After the process was finished, the answers/ideas were evaluated and were ranked. The results of the evaluation of all the answers were selected. Only the similar concepts were grouped together. After the students got the list down, they discussed the remaining responses as a group. Lecturer guided them to pass all the process. The quantity rather than the quality of ideas was the goal, that was okay for them to think out of the box.

\section{b. Meeting 2}

This meeting was planned using the same brainstorming method as in meeting 1 (cycle 2). Lecturer gave explanation again to the students about this effective brainstorming. The class was divided into 5 groups consisting 5 students each. All the steps in meeting 1 (cycle 2) were repeated in this meeting. Students did not get any difficulties to follow this strategy because they had adapted with the technique. After 15 minutes explanation, the class started the effective brainstorming, and the lecturer started to evaluate. All the answers from students were submitted to the lecturer and they were given scores for their writing.

\section{Observation}


The brainstorming strategy was applied to this class, there was only one problem when using this strategy, few students did not focused to the lecturer, so that few of them did not understand. The students' writing scores were as follows: 4 students or $16 \%$ who got < 75 ; 6 students or $24 \%$ who got scores between $76-80 ; 11$ students or $44 \%$ who got scores between 81-90; and 4 students or 16\% got the scores between 91-100. The data showed only 4 students (16\%) got the low scores. It could be proven that Brainstorming Strategy could improve Writing skill of Students on English subject, and they also had higher motivation in writing.

\section{Reflection}

From the result of the observation in cycle 2, students' scores increase than in cycle 1. The data showed the mean score for cycle 1 was $64 \%$, and for cycle 2 was $84 \%$. Based on the observation and investigation of researcher (Lecturer), it was found that students who were given brainstorming strategy could produce many effective words, good ideas, good problem solving, and interesting answers. They did not even expect to be able to make interesting paragraphs with good words.

But instead, before they were given brainstorming strategy, the words they produced were less interesting, less good ideas, and seem monotonous. Teaching and learning process by using brainstorming strategy was stopped in cycle 2, because the brainstorming strategy had delivered effective and interesting technique for improving students' writing skill, in this case was English writing skill of economic students of STIE Perbanas Surabaya.

\section{CONCLUSION}

By using brainstorming strategy, the participants (students) were more motivated in terms of writing, which at this time was English writing with a particular topic. Questions on the brainstorming sheet that have been arranged in such a way make it easier for students to generate ideas with interesting words, and of course, this could encourage students' motivation especially in English writing. If every writing lesson is given brainstorming, then the students will not easily get bored and they will love the lesson.

The analysis of the data was based on Lecturer's observation and investigation during the process of brainstorming, and also students' activity and work on the process. In cycle 1, there were 9 students or $36 \%$ who got $<75$; 5 students or $20 \%$ who got score between $76-80$; 11 students or $44 \%$ who got score between 81-90; and no students got the score between 91100. The result from cycle 1 was not satisfying because it was still out of the target. There 
were 9 students (36\%) who got low scores. So, the researcher should continue to cycle 2 with some improvements in brainstorming strategy. In cycle 2,4 students or $16 \%$ who got $<75 ; 6$ students or $24 \%$ who got scores between $76-80 ; 11$ students or $44 \%$ who got scores between 81-90; and 4 students or $16 \%$ got the scores between 91-100. In conclusion, brainstorming strategy could improve students' English Writing skill and their motivation in writing. They could produce good and effective words, and also interesting answers. Based on the fact, brainstorming strategy is suggested for teaching English Writing. By this strategy, students' motivation in writing much higher than without brainstorming strategy.

\section{REFERENCES}

Arivananthan, Meena. (2015). Brainstorming: Free-flowing creativity for problem-solving. USA: UNICEF. Online for free download at $h t t p: / / w w w$. unicef.org/knowledgeexchangel

Coulmas. Florian. Writing systems: An introduction to their linguistic analysis. Excerpt. Cambridge: Cambridge University Press. Retrieved from http://www.cambridge.org/0521782171, on May 4, 2017.

Dornyei, Z. (1994). Motivation and motivating in the foreign language classroom. The Modern Language Journal, 78 (3), 273- 284.

Dörnyei, Z. (2005). The psychology of the language learner: Individual differences in second

Dörnyei, Z. and Csizér, K. (2005). The effects of intercultural contact and tourism on language attitudes and language learning motivation. Journal of Language and Social Psychology, 24(4), 327-357.

Elkenberry, K. (2007). Brainstorming startegy: Seven questions that spur better solutions. Retrieved from http://www.sideroad.com/Meetings/brainstorming-startegy.html, on June 1, 2017

Ellis, R. (1994). The study of second language acquisition. Oxford: Oxford University Press.

Graham, S., \& Perin, D. (2007b). What we know, what we still need to know: Teaching adolescents to write. Scientific Studies in Reading,11, 313-336.

Journal of Academic Writing Vol. 6 No 1 Autumn 2016, pages 31-40, retrieved from http://dx.doi.org/10.18552/joaw.v6i1.282

Kirchhoff, Leonie. (2016). Motivation in the Writing Centre: A Peer Tutor's Experience. language acquisition. Mahwah, NJ: Lawrence Erlbaum Associates. 
Lathif, Masyhudi. (2017). Investigating Non-English Department Students' Motivation in EFL Writing. IJIET, e-ISSN 2548-8430, p-ISSN 2548-8422, Vol. 1, No. 1, January 2017.

Moelong, Lexy J. (1988). Metodologi Penelitian Kualitatif. Bandung: Remaja Rosdakarya.

Mohammad, Mohammad Fawzi M. and Ali Ahmed Hussein. (2013). Enhancing Students' Motivation to Write Essays through Brainstorming: A Comparative Study.

International Journal of Humanities and Social Science, Vol. 3, No. 9, May 2013.

Noels, K.A. (2001). New orientations in language learning motivation: Towards model of intrinsic,extrinsic, and integrative orientations and motivation.

Prakash,P. (2007). Psychological Foundation of Education. New Delhi: Kanishka Publishers.

Ryan, R. M. and Deci, E.L. (2000) 'Intrinsic and Extrinsic Motivations: Classic Definitions and New Directions' Contemporary Educational Psychology 25(1), 54-67.

Virdaus, Varia Virdania. (2016). ENHANCING LISTENING ABILITY THROUGH TPT BY USING ADOBE AUDITION 1.5. Cakrawala Pendidikan, 18 (1). pp. 36-46. ISSN 1410-9883, retrieved from http://digilib.stkippgri-blitar.ac.id/463/ on April 28, 2017.

Walker, A. L. (1952) 'Motivation'. College Composition and Communication 3(3), 3.

Z. Dörnyei \& R.Oxford, R.L. \& Shearin, J. (1996). Language learning motivation in a new key. In Oxford, R.L. (Ed.). Language Learning Motivation: Pathways to the New Century. Honolulu: University of Hawaii Press. 121-44. 